\title{
A method for the deliberate and deliberative selection of policy instrument mixes for climate change adaptation
}

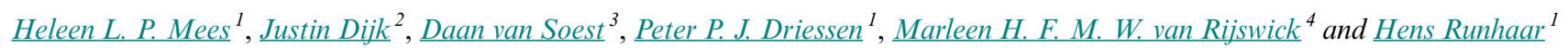

\begin{abstract}
Policy instruments can help put climate adaptation plans into action. Here, we propose a method for the systematic assessment and selection of policy instruments for stimulating adaptation action. The multi-disciplinary set of six assessment criteria is derived from economics, policy, and legal studies. These criteria are specified for the purpose of climate adaptation by taking into account four challenges to the governance of climate adaptation: uncertainty, spatial diversity, controversy, and social complexity. The six criteria and four challenges are integrated into a step-wise method that enables the selection of instruments starting from a generic assessment and ending with a specific assessment of policy instrument mixes for the stimulation of a specific adaptation measure. We then apply the method to three examples of adaptation measures. The method's merits lie in enabling deliberate choices through a holistic and comprehensive set of adaptation specific criteria, as well as deliberative choices by offering a stepwise method that structures an informed dialog on instrument selection. Although the method was created and applied by scientific experts, policy-makers can also use the method.
\end{abstract}

Key Words: adaptation to climate change; local governance; method; policy instrument selection

\section{INTRODUCTION}

Although, in the past decade, efforts to plan for climate adaptation have increased, in particular, in developed countries (Biesbroek et al. 2010, Preston et al. 2011), their translation into actual adaptation practice is still scarce and constrained by multiple barriers (Biesbroek et al. 2010, Archie et al. 2012, Bierbaum et al. 2013). Although the climate adaptation debate nowadays includes the "how to adapt" question (Wilby and Vaughan 2011:271), so far, the literature offers little insight into how adaptation plans are put into practice, and by whom (Dovers and Hezri 2010, Berrang-Ford et al. 2011). Given their collective nature, adaptation plans often appear to be initiated and developed by governments at various levels (Johnson and Priest 2008, BerrangFord et al. 2011, Mees and Driessen 2011, Runhaar et al. 2012). Governments can make a conscious choice about allocations of responsibilities for adaptation; they can decide to transfer certain responsibilities for adaptation action to private actors such as citizens, civil organizations, and businesses (Mees et al. 2012). They can also incentivize private adaptation action through policy instruments (Berkhout 2005, Fankhauser et al. 2008, Wilby and Vaughan 2011). However, which instruments are suitable for climate adaptation purposes, and which criteria are important for the selection of those instruments? The how and by whom questions are interrelated and address the topic of governance modes and available instruments for climate adaptation (D. Huitema et al. unpublished manuscript).

The selection of policy instruments is a classic dilemma for policymakers and a recurrent research topic in policy studies (e.g., Howlett 1991, Glasbergen 1992, Bemelmans-Videc et al. 1998, Gunningham and Grabosky 1998). So far, there is limited insight into which policy instruments are available for promoting adaptation to climate change and how they perform against criteria such as effectiveness and legitimacy. Insights from other policy domains are not easily transferable; the literature suggests that the performance of policy instruments is heavily influenced by the specific problem characteristics (Hellegers and Van Ierland 2003).

We argue that certain specific characteristics of climate adaptation offer challenges to its governance, and these should be taken into account when selecting policy instruments for climate adaptation. These challenges are uncertainty, spatial diversity, controversy, and social complexity (Termeer et al. 2011, Mees et al. 2012, van Buuren et al. 2014). Uncertainty relates to the climate system itself, its effects on society, and the costs, benefits, and effectiveness of adaptation measures (e.g., Füssel 2007, Adger et al. 2009, Van Vuuren et al. 2011). The long-term character of climate change and, consequently, the long-term planning horizon it requires clashes with short-term policy and political cycles and hence exacerbates this uncertainty (e.g., Fankhauser et al. 1999, Dovers and Hezri 2010). Spatial diversity of climate impacts occurs between and within regions, city districts, and socioeconomic groups in society, leading to differential vulnerabilities and inequalities (Lindley et al. 2007, Aaheim et al. 2010). Controversy refers to contradictory perceptions of adaptation problems, goals, and measures (Adger et al. 2009, Hinkel et al. 2010). Social complexity refers to the multi-level, multi-sector, and multi-actor character of adaptation action, leading to unclear and fragmented responsibilities and institutional voids (e.g., Urwin and Jordan 2008, Termeer et al. 2011, Mees et al. 2012). We argue that these challenges give direction to the objectives that policy instruments should fulfil, and they should therefore influence criteria for the selection of policy instruments. For example, the uptake of green roofs by private actors for the retention of heavy rainfall is hampered by the uncertainties regarding the costs and benefits of green roofs. Effectiveness, i.e., achieving sufficient levels of adaptation action to achieve a critical mass of green roofs for rainfall retention, will be an important criterion for governments to stimulate the uptake of green roofs by private actors. Hence, governments might decide to employ a technical requirement for green roofs through a

\footnotetext{
${ }^{1}$ Copernicus Institute of Sustainable Development, Utrecht University, ${ }^{2}$ IVM and Department of Spatial Economics, VU University Amsterdam, ${ }^{3}$ Department of Economics and Tilburg Sustainability Center, Tilburg University, ${ }^{4}$ Utrecht Center for Water, Oceans and Sustainability Law, Utrecht University
} 
building code as the key policy instrument to secure sufficient adaptation action (Mees et al. 2013).

Here, a team of experts from legal, policy, and economic studies develops and applies an ex-ante method for the systematic selection of policy instruments for climate adaptation action, taking into account the particular governance challenges of climate adaptation. This work fills a gap in climate adaptation governance literature by contributing to the question of how adaptation can be put into practice. The method may also support public policy-makers in systematically assessing and selecting policy instruments for climate adaptation and justifying their choices. Furthermore, the method allows for the design of policy instrument mixes, a topic that has not yet been elaborated upon in much detail in policy studies. Various authors have claimed that in environmental policy, the employment of a mix of policy instruments is often preferable for reaching multiple policy objectives and target groups because policy instruments may complement each other and compensate each other's weaknesses (see Taylor et al. 2012). Conceptualizations and empirical evidence, however, are limited (Glasbergen 1992, Oikonomou and Jepma 2008, Weber et al. 2014). In part, this is explained by the inherent nature of the identification of appropriate policy instrument mixes: It strongly depends on what criteria are considered most important in a particular adaptation context, what weights are put on those criteria (e.g., in the case of uneven distribution of vulnerabilities, fairness may be the most important criterion), and the extent to which compensation between criteria is considered feasible or desirable.

Specifically, we address the following two questions: How can criteria for the selection of policy instruments for climate adaptation be specified according to the challenges to the governance of climate adaptation? How can policy instrument mixes be selected systematically based on these criteria? By means of an expert judgment applied to three examples of urban adaptation measures, we demonstrate the usefulness of the method. We first present a framework for the assessment of policy instruments, followed by an explanation of the method. We then describe three examples of urban adaptation measures (green roofs, flood-resilient building, and behavioral measures to extreme heat), illustrate the method through its application to these examples, and discuss the results of our exercise. We end with conclusions and some reflections.

\section{ANALYTICAL FRAMEWORK}

\section{Policy instruments: a typology}

Policy instruments are "effecting tools", which are meant to have an effect on behavior (Hood 2007:139). They are often referred to as the "tools of government"(Hood 1983). We use the following definition of a policy instrument: "a deliberate structured effort by governors to solve a policy problem by modifying actions of the governed" (Brukas and Sallnäs 2012:605). We take the perspective of local urban policy-makers as the governors who can employ policy instruments to stimulate adaptation action, or alternatively, use the market by stimulating private actors to employ policy instruments to regulate the market (Fankhauser et al. 2008) or use the governance network (Vabo and Røiseland 2012). This government-led perspective is distinct from more autonomously-led adaptation by organizations, which have their own drivers for taking action (e.g., Berkhout et al. 2006, Wilby and Vaughan 2011, Berkhout 2012), or by individuals (e.g., Tompkins and Eakin 2012, Wamsler and Brink 2014). To identify systematically the variety of policy instruments for adaptation, we use a two-dimensional classification scheme that includes the following.

- The type of governance arrangement: We distinguish between hierarchical public arrangements with governments as the main governing actors; interactive arrangements in which governments and private actors jointly govern; and market governance in which the initiative to implement adaptation measures is left to private actors (e.g., companies or homeowners) and civil society. These three arrangements are generally identified in the governance literature, albeit sometimes under different headings (Thompson et al. 1991, Gunningham and Sinclair 2002, Kjær 2004, Driessen et al. 2012).

- The associated policy instruments and their underlying rationales: In the literature, three types of policy instruments are usually distinguished: legal (or regulatory) instruments, economic instruments, and communicative (or informational) instruments (Hood 1983, Glasbergen 1992, Vedung 1998, Gunningham and Sinclair 2002, Brukas and Sallnäs 2012). Each type is based on a different rationale regarding the way actors are steered: by restricting or allowing behavioral options (legal instruments), by changing the cost-to-benefit ratios of these options (economic instruments), or by informing about options (communication instruments).

We classify policy instruments for adaptation according to these two dimensions (Table 1). Most instruments can potentially be employed in any type of governance arrangement, although regulatory instruments tend to dominate with hierarchical arrangements, and economic instruments with market arrangements. In the category of legal instruments, for instance, one could introduce a building requirement for houses in floodprone areas (Aerts and Botzen 2011) or mandatory labels that specify the vulnerability of a house to floods. Economic instruments for adaptation could, for instance, comprise insurance fee discounts if property owners invest in measures that reduce flood risks, such as green roofs (see Kleindorfer and Kunreuther 1999, Kunreuther and Pauly 2006). A typical communication instrument is the public information campaign, for example, advice from municipal health services on how to avoid heat stress, a phenomenon that is expected to increase in frequency as a consequence of climate change (Runhaar et al. 2012). Our list of instruments is not exhaustive and is necessarily incomplete (Table 1). We only include those instruments that are typically used to address environmental problems (see Glasbergen 1992, Vedung 1998, Hellegers and Van Ierland 2003, Wurzel et al. 2003, Taylor et al. 2012, Lockie 2013), which are therefore potential candidates for climate adaptation policies. This does not mean that all listed instruments are equally suitable in the context of specific adaptation measures, as we show in the adaptation examples. 
Table 1. A list of promising policy instruments for promoting adaptation to climate change.

\begin{tabular}{lccc}
\hline \hline Type of instrument & Hierarchical (public) governance & Interactive governance & Market (private) governance \\
\hline Legal instruments & $\begin{array}{c}\text { - Technical requirements, including } \\
\text { quota, zoning, relocation, and } \\
\text { prescription of best available technology } \\
\text { or best practices (TR) } \\
\text { - Performance standards (PS) }\end{array}$ & $\begin{array}{c}\text { - Contractual agreements or covenants } \\
\text { (CA) }\end{array}$ & $\begin{array}{c}\text { - Private labeling, including } \\
\text { investor requirements (PL) }\end{array}$ \\
$\begin{array}{l}\text { Economic instruments } \\
\text { - Mandatory labeling (ML) }\end{array}$ & $\begin{array}{c}\text { - Subsidies, including reduction of fees } \\
\text { (SU) }\end{array}$ & - Smart subsidies or auctions (SSU) & - Insurances fee differentiation \\
(INS) & - Taxes (TAX) & - Tradable permits (TP) & - Product information (PI) \\
$\begin{array}{l}\text { Communicative } \\
\text { instruments }\end{array}$ & - Public information campaigns (PI) & & \\
\hline
\end{tabular}

\section{Criteria for policy instrument selection}

A variety of performance criteria might apply for climate adaptation. We use a multi-disciplinary set of most commonly applied assessment criteria for policy analysis as derived from economics, policy, and legal studies: effectiveness, efficiency, legitimacy, accountability, legal certainty, and fairness (e.g., Nelissen 2002, Crabbé and Leroy 2008). This set is also inspired by the "thick analysis framework", as employed by Adger et al. (2003), which is meant to foster interdisciplinarity and pluralism to overcome a narrow approach in environmental research. We next define the six criteria and explicitly link them to the four challenges of uncertainty, spatial diversity, controversy, and social complexity.

From economics, we derived the criteria of effectiveness and efficiency. Effectiveness is commonly understood as the extent to which policy goals are achieved by means of the selected policy instruments and the available resources; in the case of climate adaptation, it is about securing sufficient adaptation action. Effectiveness is influenced by uncertainty, in the sense that high uncertainties regarding the spatial and temporal impacts of climate change could deter people from taking adaptation action, resulting in non- or under-adaptation (Adger et al. 2009, Gifford 2011). In such circumstances, policy instruments are called for that steer or even force people to adapt, to reach sufficient levels of adaptation action.

Efficiency is about the optimum allocation of scarce resources, ensuring that an adaptation good is provided at the lowest cost. Efficiency is also affected by uncertainty, but in the opposite direction: governments might take too much action too soon out of precaution, resulting in costly over-adaptation (Driessen and Van Rijswick 2011). In such cases, policy instruments are needed that promote experimentation and flexible adaptation action that can be adjusted easily over time and in light of the long-term planning horizon needed for adaptation (Fankhauser et al. 1999, Huitema et al. 2009, Gupta et al. 2010, Keessen and Van Rijswick 2012). Furthermore, efficiency is influenced by spatial diversity in the sense that each specific location or region might be affected in different ways. In such situations, policy instruments are needed that promote adaptation action tailored to each specific location to minimize costs.
From policy studies, we derived the criteria of legitimacy and accountability. Legitimacy, from a policy and legal-scientific point of view, is about the acceptance of authority and justification of power (Bernstein 2005, Bekkers and Edwards 2007, Dingwerth 2007). Controversies around the problems, goals, and measures of adaptation affect the criterion of output legitimacy, i.e., the perceived effectiveness among stakeholders (Biermann and Gupta 2011), often operationalized as the acceptance of the outcomes of a governance process (Bekkers and Edwards 2007). This is because the different value systems and interests of actors might make a high acceptance level of adaptation measures among stakeholders problematic. If this is the case, policy instruments must be selected based on their ability to stimulate acceptance of their effects by all relevant stakeholder groups that are faced with the adaptation problem at stake. Furthermore, social complexities affect the criterion of input legitimacy, i.e., inclusion of all interests at stake (Bekkers and Edwards 2007, Few et al. 2007, Paavola 2008). In cases of high social complexity, policy instruments must be selected based on their ability to serve all relevant interests without excluding affected parties (Paavola 2008).

Accountability is about stakeholders and society being able to scrutinize the actions of policy-makers. This can be achieved through, for instance, clarity of responsibilities (Botchway 2001) and transparency of information on the content and process of policy-making (Gupta 2010). Again, a large extent of social complexity leads to fragmented and ambiguous responsibilities for adaptation (Urwin and Jordan 2008). Hence, policy instruments are needed that support a clear allocation and transparency of responsibilities for adaptation action.

From legal studies, we derived the criteria of legal certainty and fairness. Legal certainty means that the law must provide those subject to it with the ability to regulate their conduct. Legal certainty is internationally recognized as a central requirement for the rule of law and as a grounding value for the legality of legislative and administrative measures taken by public authorities (Fuller 1969, Radbruch 1970, Popelier 2000). In case of high uncertainty regarding the spatial and temporal effects of climate impacts, people need to know where they stand in terms of regulation so that they can align their adaptation action in 
Table 2. Adaptation-specific performance criteria for the selection of policy instruments.

\begin{tabular}{|c|c|c|c|}
\hline $\begin{array}{l}\text { Governance } \\
\text { challenge }\end{array}$ & Criteria at risk & Explanation & $\begin{array}{c}\text { Performance criteria for the selection of } \\
\text { policy instruments for climate } \\
\text { adaptation }\end{array}$ \\
\hline \multirow[t]{4}{*}{ Uncertainty } & $\begin{array}{l}\text { Effectiveness; securing } \\
\text { (adaptation) goals }\end{array}$ & $\begin{array}{l}\text { Uncertainties regarding climate impacts as well as the } \\
\text { costs, benefits, and effectiveness of adaptation } \\
\text { measures deter people from taking action, resulting in } \\
\text { non- or underadaptation }\end{array}$ & $\begin{array}{l}\text { Steers toward supplying sufficient levels } \\
\text { of adaptation goods/services (the more } \\
\text { coercive, the more steering power) }\end{array}$ \\
\hline & $\begin{array}{l}\text { Fairness; reasonable distribution } \\
\text { of burdens intra- and } \\
\text { intergenerationally }\end{array}$ & $\begin{array}{l}\text { Uncertainties regarding the spatial and temporal } \\
\text { effects of climate change mean that the precautionary } \\
\text { principle should be applied to ensure that sufficient } \\
\text { action is taken to guarantee a minimum safety level for } \\
\text { everyone in society, spatially and temporally }\end{array}$ & $\begin{array}{l}\text { Steers toward supplying sufficient levels } \\
\text { of adaptation goods/services for } \\
\text { everyone now and in the future }\end{array}$ \\
\hline & $\begin{array}{l}\text { Legal certainty; the law must } \\
\text { provide those subject to it with } \\
\text { the ability to regulate their } \\
\text { conduct }\end{array}$ & $\begin{array}{l}\text { Because of uncertainties regarding spatial and } \\
\text { temporal effects of climate change and its impacts on } \\
\text { society, people need to know where they stand in terms } \\
\text { of regulations for a considerable period of time so that } \\
\text { they can fine-tune their adaptation actions in } \\
\text { accordance with these regulations }\end{array}$ & $\begin{array}{l}\text { Offers legal certainty through clear, } \\
\text { understandable, and stable rules to } \\
\text { which people can conform }\end{array}$ \\
\hline & $\begin{array}{l}\text { Efficiency; supply of flexible } \\
\text { adaptation goods to achieve } \\
\text { lowest cost }\end{array}$ & $\begin{array}{l}\text { Uncertainties regarding climate impacts could entice } \\
\text { (governments to take) actions that are overdone and } \\
\text { costly, resulting in over-adaptation }\end{array}$ & $\begin{array}{l}\text { Promotes flexible adaptation solutions } \\
\text { and measures that can be easily adjusted } \\
\text { over time to minimize costs }\end{array}$ \\
\hline \multirow[t]{2}{*}{$\begin{array}{l}\text { Spatial } \\
\text { diversity }\end{array}$} & $\begin{array}{l}\text { Fairness; reasonable distribution } \\
\text { of burdens according to carrying } \\
\text { capacity }\end{array}$ & $\begin{array}{l}\text { The spatial diversity of climate impacts leads to } \\
\text { differential vulnerabilities owing to diversities in } \\
\text { exposure to climate impacts, sensitivity to those } \\
\text { impacts, and capacity to adapt among people, districts, } \\
\text { regions, etc. }\end{array}$ & $\begin{array}{l}\text { Steers toward supplying sufficient levels } \\
\text { of adaptation goods to hotspots most } \\
\text { vulnerable to climate impacts while } \\
\text { recovering a fair share of the costs of } \\
\text { adaptation action from those who } \\
\text { benefit }\end{array}$ \\
\hline & $\begin{array}{l}\text { Efficiency; supply of spatially } \\
\text { tailored adaptation goods to } \\
\text { achieve lowest cost }\end{array}$ & $\begin{array}{l}\text { The spatial diversity of climate impacts means that } \\
\text { each specific location, region, building, etc. is affected } \\
\text { differently and might need different responses }\end{array}$ & $\begin{array}{l}\text { Promotes diverse adaptation action that } \\
\text { is tailored to a specific location to } \\
\text { minimize costs }\end{array}$ \\
\hline Controversy & $\begin{array}{l}\text { Output legitimacy; support of } \\
\text { stakeholders for an adaptation } \\
\text { goal, solution, and the decision } \\
\text { process }\end{array}$ & $\begin{array}{l}\text { Controversies around adaptation goals and solutions } \\
\text { reflect different interests, principles, and value systems } \\
\text { among actors, resulting in problematic support for } \\
\text { adaptation policies }\end{array}$ & $\begin{array}{l}\text { Stimulates acceptance of its effects on all } \\
\text { relevant stakeholders }\end{array}$ \\
\hline \multirow[t]{2}{*}{$\begin{array}{l}\text { Social } \\
\text { complexity }\end{array}$} & $\begin{array}{l}\text { Input legitimacy; inclusion of all } \\
\text { relevant interests }\end{array}$ & $\begin{array}{l}\text { Social complexities mean that various target groups, } \\
\text { sectors, and levels are affected by climate impacts, so } \\
\text { these should be consciously considered in the policy }\end{array}$ & $\begin{array}{l}\text { Serves all relevant interests that are } \\
\text { influenced by the policy without } \\
\text { excluding actors or groups that have } \\
\text { something at stake }\end{array}$ \\
\hline & $\begin{array}{l}\text { Accountability; reciprocal clarity } \\
\text { and transparency of governors } \\
\text { and the governed }\end{array}$ & $\begin{array}{l}\text { Social complexities lead to the fragmentation and } \\
\text { ambiguity of responsibilities, hampering clear } \\
\text { accountability structures }\end{array}$ & $\begin{array}{l}\text { Supports the allocation and } \\
\text { transparency of responsibilities for } \\
\text { adaptation action for both the governors } \\
\text { and the governed }\end{array}$ \\
\hline
\end{tabular}

accordance with these regulations. Therefore, policy instruments must be selected for their ability to offer legal certainty through stable and understandable rules.

Fairness is interpreted here as distributive fairness, i.e., the fair allocation of burdens and benefits for climate adaptation action. Adaptation is claimed to particularly raise the issue of fair benefit sharing, i.e., the distribution of scarce adaptation resources among recipients of benefits. This is because adaptation action generates local goods for specific targets rather than global common goods, as is the case with mitigation (e.g., Paavola and Adger 2006, Grasso 2007, Jagers and Duus-Otterström 2008, Driessen and Van Rijswick 2011). Fairness is influenced by two governance challenges. Uncertainty regarding the spatial and temporal effects of climate change activates the precautionary principle so that inter- and intra-generational equity is considered. In such a situation, policy instruments are needed that steer toward supplying sufficient levels of adaptation goods for everybody in society. The second challenge, the spatial diversity of climate impacts, means that some groups and regions are more vulnerable than others. In such cases, policy instruments must help to prioritize the supply of sufficient levels of adaptation action to specific vulnerable hotspots by putting the most vulnerable first (Paavola and Adger 2006, Grasso 2007). In doing so, policy instruments can also try to recover the cost of adaptation action from those who profit from that action (Atkinson et al. 2000, Driessen and Van Rijswick 2011).

From these criteria and challenges, we derived nine specific adaptation criteria (Table 2). We use these nine criteria to assess the performance of the identified policy instruments (Table 1). 


\section{METHOD}

\section{Step-wise approach}

As a team of scientific experts, we created a method comprising a step-wise approach for the purpose of policy instruments selection. The method starts from the point that a suitable adaptation measure has been selected based on the adaptation issue and goal at hand, for instance, through a multi-criteria analysis applied to various adaptation options (e.g., de Bruin et al. 2009). Clearly, the selection of adaptation measures would equally benefit from a deliberate rather than a routine approach based on past experience (Tennekes et al. 2014), but that is beyond the scope of this paper. Our method is designed to select policy instruments for predefined adaptation measures and comprises four steps:

1. General assessment of policy instruments: The purpose of this step is to identfy an appropriate set of policy instruments for climate adaptation in general. This can be done by assessing the promising policy instruments we identified previously (Table 1) using the nine performance criteria (Table 2). For the sake of simplicity, we propose using a three-point ordinal scale whereby each instrument receives a high, medium, or low score on each criterion.

2. Specific assessment of policy instruments for a certain adaptation measure: To calibrate the results, a sensitivity check is performed on the suitability and scores of policy instruments from Step 1 for a specific adaptation measure.

3. Assessment of the four governance challenges for a certain adaptation measure: The purpose of this step is to identify the relative importance of the performance criteria for a specific adaptation measure. This can be done by scoring the extent to which the four challenges manifest themselves for that specific adaptation measure, using the same threepoint scale of high, medium, and low.

4. Specific selection of appropriate policy instruments for a certain adaptation measure: The purpose of this final step is to identify appropriate combinations of instruments per adaptation measure. This can be done by checking which instruments perform best on the most relevant performance criteria (combining steps 1 and 3). Next, one can look for combinations of instruments that score well on different relevant criteria, thus complementing each other and/or compensating for each other's weaknesses, and/or by combining instruments that cover different target groups, and/or by sequentially introducing different instruments.

The four adaptation challenges play an important role in the method. First, they shape the formulation of criteria for the selection of instruments for adaptation in general (Step 1). Second, they determine the weight of the criteria for each specific adaptation measure (Step 3).

\section{Explicating the method}

The method is designed to accommodate an interactive and deliberative process. The idea is that the steps are completed as a joint exercise by a multi-disciplinary team of experts and/or policy-makers. The underlying assumption of the method is that potential biases can be minimized by using a holistic set of six assessment criteria comprising different rationales for policy- making and by using the collective knowledge, perspectives, values, and interests of a multi-disciplinary team. For an illustration, we performed this exercise as a multi-disciplinary team of six experts from economics, policy, and legal studies. Initially, the assessments in steps 1 and 3 were done individually by each expert. During two intense, interactive workshops, we exchanged argumentations for these individual assessments, occasionally had discussions, reached agreement on certain scores, and validated the ultimate scores by combining and/or contrasting the argumentations. Hence, the scores are based on a common judgment and interpretation of the team and represent indications of the suitability of an instrument relative to the other instruments rather than absolute scores. We found a three-point scale to be sufficiently differentiating without giving a false sense of accuracy; more refined scales increase the complexity of the method without making it necessarily more robust. We argue that the robustness of the method lies in the use of multiple criteria by experts of multiple disciplinary backgrounds as well as the deliberation on the argumentation of scores.

\section{ADAPTATION MEASURES USED FOR THE ILLUSTRATION}

We opted for three adaptation measures that are employed by the public authorities of Rotterdam, a frontrunner in adaptation planning (Mees and Driessen 2011): (1) green roofs for stormwater retention, (2) flood resilient building for water safety, and (3) behavioral adaptation to extreme heat. All three examples represent urban adaptation measures. While the examples were selected primarily for practical reasons (the team has relevant know-how and experience with these examples from previous empirical work), they have the fringe benefit that they represent privately provided goods that serve public adaptation goals (see Tompkins and Eakin 2012) as well as private goals. This makes them particularly relevant for our research because local governors need the private sector (citizens and organizations) to attain the aspired public adaptation good; therefore, governors have a motive to incentivize the private sector to implement these measures through policy instruments.

The three examples purposely differ in the type of adaptation issue they address, assuming that this will lead to differences in the extent to which the four adaptation challenges manifest themselves across the examples. The examples are illustrative of the application of our method for the selection of instrument mixes and are not meant to be representative of the performance of policy instruments for climate adaptation. This would be impossible anyway because climate adaptation encompasses a wide variety of risks from climate change, as well as a wide variety of possible measures (Runhaar et al. 2012). We briefly describe the three adaptation measures before sharing the results obtained through the application of the method by the expert group.

Green roofs are roofs with vegetation. They help to store excessive rainfall and also reduce excessive heat build-up in houses. Green roofs are often promoted as "no-regrets" adaptation measures: even if their effects on climate adaptation are uncertain or unknown, they have co-benefits for property owners and society at large. Nevertheless, autonomous installations by private actors have not yet occurred widely. Green roofs are generally not considered by private actors because of an imbalance between high short-term installation costs and the slow reaping of benefits 
Table 3. General assessment of 11 policy instruments. See Table 1 for policy instruments and Table 2 for performance criteria.

\begin{tabular}{|c|c|c|c|c|c|c|c|c|c|c|c|c|c|}
\hline \multirow[b]{2}{*}{ Challenge } & \multirow[b]{2}{*}{ Criterion } & \multirow[b]{2}{*}{ Indicator to assess a policy instrument } & \multicolumn{11}{|c|}{ Policy instrument } \\
\hline & & & TR & PS & ML & $\mathrm{SU}$ & TAX & PI & $\mathrm{CA}$ & SSU & $\mathrm{TP}$ & PLB & INS \\
\hline \multirow[t]{4}{*}{ Uncertainty } & Effectiveness & $\begin{array}{l}\text { Steers toward supplying sufficient levels of adaptation } \\
\text { goods/services (the more coercive, the more steering } \\
\text { power) }\end{array}$ & $\mathrm{H} \dagger$ & M & $\mathrm{L}$ & $\mathrm{L}$ & $\mathrm{M}$ & $\mathrm{L}$ & $\mathrm{M}$ & $\mathrm{L}$ & $\mathrm{H}$ & $\mathrm{L}$ & $\mathrm{M}$ \\
\hline & Fairness & $\begin{array}{l}\text { Steers toward supplying sufficient levels of adaptation } \\
\text { goods/services for everyone now and in the future }\end{array}$ & M & M & $\mathrm{L}$ & $\mathrm{L}$ & M & $\mathrm{L}$ & $\mathrm{L}$ & $\mathrm{L}$ & M & $\mathrm{L}$ & $\mathrm{L}$ \\
\hline & $\begin{array}{l}\text { Legal } \\
\text { certainty }\end{array}$ & $\begin{array}{l}\text { Offers legal certainty through clear, understandable, } \\
\text { and stable rules to which people can conform }\end{array}$ & $\mathrm{H}$ & $\mathrm{H}$ & M & M & $\mathrm{H}$ & $\mathrm{L}$ & M & M & $\mathrm{H}$ & M & M \\
\hline & Efficiency & $\begin{array}{l}\text { Promotes flexible adaptation solutions and measures } \\
\text { that can be adjusted easily over time to minimize costs }\end{array}$ & $\mathrm{L}$ & $\mathrm{H}$ & M & M & M & $\mathrm{H}$ & M & $\mathrm{H}$ & $\mathrm{H}$ & $\mathrm{H}$ & $\mathrm{H}$ \\
\hline \multirow[t]{2}{*}{$\begin{array}{l}\text { Spatial } \\
\text { diversity }\end{array}$} & Fairness & $\begin{array}{l}\text { Steers toward supplying sufficient levels of adaptation } \\
\text { goods to hotspots most vulnerable to climate impacts } \\
\text { while recovering a fair share of the costs of adaptation } \\
\text { action from those who benefit }\end{array}$ & $\mathrm{H}$ & M & M & M & $\mathrm{H}$ & M & $\mathrm{H}$ & $\mathrm{H}$ & $\mathrm{H}$ & $\mathrm{L}$ & $\mathrm{L}$ \\
\hline & Efficiency & $\begin{array}{l}\text { Promotes diverse adaptation action that is tailored to a } \\
\text { specific location to minimize costs }\end{array}$ & $\mathrm{L}$ & M & $\mathrm{L}$ & $\mathrm{L}$ & $\mathrm{L}$ & $\mathrm{H}$ & $\mathrm{H}$ & $\mathrm{H}$ & $\mathrm{H}$ & $\mathrm{L}$ & M \\
\hline Controversy & Legitimacy & $\begin{array}{l}\text { Stimulates acceptance of its impacts by all relevant } \\
\text { stakeholders }\end{array}$ & M & M & M & M & $\mathrm{L}$ & $\mathrm{H}$ & M & M & M & M & M \\
\hline \multirow[t]{2}{*}{$\begin{array}{l}\text { Social } \\
\text { complexity }\end{array}$} & Legitimacy & $\begin{array}{l}\text { Serves all relevant interests that are influenced by the } \\
\text { policy without excluding actors or groups that have } \\
\text { something at stake }\end{array}$ & $\mathrm{L}$ & $\mathrm{L}$ & $\mathrm{L}$ & $\mathrm{L}$ & $\mathrm{L}$ & M & M & $\mathrm{L}$ & $\mathrm{L}$ & $\mathrm{L}$ & $\mathrm{L}$ \\
\hline & $\begin{array}{l}\text { Accountab- } \\
\text { ility }\end{array}$ & $\begin{array}{l}\text { Supports the allocation and transparency of } \\
\text { responsibilities for adaptation action for both the } \\
\text { governors and the governed }\end{array}$ & $\mathrm{H}$ & $\mathrm{M}$ & $\mathrm{L}$ & $\mathrm{H}$ & $\mathrm{H}$ & $\mathrm{L}$ & $\mathrm{H}$ & $\mathrm{H}$ & $\mathrm{H}$ & $\mathrm{L}$ & $\mathrm{H}$ \\
\hline
\end{tabular}

Note: The individual assessments for the full set of instruments are documented in a report that is available online: http:// knowledgeforclimate.climateresearchnetherlands.nl/.

$\dagger$ Performance criteria were assessed using a qualitative score: $\mathrm{H}=$ high, $\mathrm{M}=$ medium, $\mathrm{L}=$ low.

over time, among other reasons. If installation is left to private actors, adaptation action is likely to be insufficient and fragmented (Mees et al. 2013). Moreover, adaptation action will probably not occur in those parts of the city most prone to surface water flooding or heat stress. Consequently, policy-makers have started to employ a wide range of policy instruments to promote the uptake of green roofs (Carter and Fowler 2008), of which economic instruments are most commonly applied (Mees et al. 2013).

Flood-resilient building measures are measures applied to new and existing houses and other buildings that reduce the impact of a flood, i.e., prevent flood damage from occurring. These measures are an alternative to flood walls and elevated buildings and are often applied in unembanked areas. They are also referred to as the wet-proofing or dry-proofing of buildings. In the former case, water is allowed to enter the building, and the finishing of floors and walls is adapted to withstand water. In the latter case, the building itself provides watertight protection for itself and its surroundings. The application of flood-resilient building measures depends very much on the specifics of the location and its vulnerability to flooding. A common way to ensure the implementation of these types of measures is via legal instruments of spatial planning such as master plans and building codes, or to specify them as technical requirements through contractual agreements (Mees et al. 2014).

Behavioral measures to adapt to extreme heat range from drinking more water and refraining from heavy exercise to ventilating rooms, seeking cooler places, and closing window shutters. These types of measures are meant to keep the body temperature under a certain level to prevent heat stress, morbidity, and even mortality, particularly among vulnerable population groups such as the elderly and chronically ill (Schär and Jendritzky 2004). Behavioral measures to combat extreme heat are generally advised through heat health early warning systems and response plans (Lowe et al. 2011). A key governance issue lies in the fragmentation of responsibilities among the multiple public and private actors involved (World Health Organization 2007), ranging from officers of public health and social services to health practitioners, caretakers in residential homes, and citizens or their family and neighbors. A commonly applied instrument is the public health information campaign (World Health Organization 2007).

\section{APPLYING THE METHOD: AN ILLUSTRATION}

\section{Step 1: general assessment of policy instruments}

We assessed all policy instruments (Table 1) on the nine criteria (Table 2), resulting in scores for all policy instruments (Table 3). Here, we give an example of the argumentation behind these scores. A technical requirement, for instance one that prescribes green roofs for new developments with flat roofs, scores high on effectiveness (Table 3). The argumentation for this score is that a technical requirement offers a high certainty that the adaptation goal is reached through its coercive nature, as long as its application can be monitored and enforced. By contrast, a smart subsidy scores low on effectiveness. Consider, for instance, a subsidy for green roofs that is allocated through an auction 
mechanism that ensures that only the low-cost actors are selected to adapt (see Ferraro 2008). A smart subsidy is a voluntary instrument: actors can decide not to participate, and, in the case that an auction is used, only the low-cost adapters will receive a subsidy. Hence, a smart subsidy is expected to offer too little of that adaptation measure.

On the other hand, a technical requirement scores low on the two efficiency criteria, whereas a smart subsidy scores high on these efficiency criteria. A technical requirement is a one-size-fits-all instrument that does not select the least-cost suppliers and does not offer any flexibility for adjustment over time or for tailormade adaptation action (unless it is formulated by way of describing several allowed best practices). By contrast, a smart subsidy instrument allows for the selection of the least-cost actors to implement the adaptation measure. Furthermore, it offers flexibility over time because a smart subsidy is only introduced as and when adaptation action is needed and can be applied for a certain specific vulnerable region only. An example of the scores and argumentations for one instrument, the technical requirement, is provided in Appendix 1.

\section{Step 2: specific assessment of policy instruments for a certain adaptation measure}

By conducting a sensitivity check, we discovered that certain instruments were less suitable for the three adaptation measures than others. Taxes were disregarded because they are intended to discourage harmful behavior rather than to encourage good behavior such as the implementation of adaptation measures. It is, for instance, difficult to imagine taxing an individual for not wanting to install a green roof. Similarly, tradable permits seem less appropriate for these adaptation measures because they are also meant to discourage harmful behavior by putting a price on carbon emissions or the use of scarce resources. These two instruments were therefore disregarded in steps 3 and 4 for the three adaptation measures in our study, but they may be useful for other adaptation policies that, for instance, intend to limit the use of fresh water in case of scarcity. Furthermore, we fine-tuned the scores of the policy instruments for the criterion of accountability based on the characteristics of one of the adaptation measures (Table 3). Measures for behavioral adaptation to extreme heat are rather difficult to trace and monitor in practice compared to the other two types of measures, resulting in lower accountability. For instance, how would one monitor whether people drink sufficient water? For behavioral adaptation to extreme heat, we therefore lowered the scores for the criterion of accountability by one grade, i.e., from high to medium for policy instruments with a high score, and from medium to low for instruments with a medium score.

\section{Step 3: assessment of the four governance challenges for a certain adaptation measure}

In this step, we assessed the extent to which the four adaptation challenges manifest themselves in the three adaptation measures (Table 4). It shows that the challenge of uncertainty has the highest presence in the example of green roofs. This is because there is uncertainty in many aspects: in terms of the frequency and intensity of rainfall and the effects this rainfall may have on the built environment. Furthermore, there is uncertainty about the amount of rainfall that can be retained by a green roof, as well as what its private benefits are, some of which are difficult to convert to monetary values. This causes high uncertainty with respect to the return on investment of a green roof installation. Uncertainty for the other two adaptation measures is somewhat lower due to greater predictability of sea level rise, river discharge levels, and hot days, and because of the more advanced knowledge of costs and benefits of these adaptation measures. The challenge of social complexity is most prevalent in behavioral adaptation to extreme heat. This is because there are potentially many different actors and organizations involved, both in the public and in the private sector, some of which are difficult to steer and monitor (such as vulnerable people and their social networks). Although different public and private organizations are involved in green roofs and flood-resilient building measures, there is more clarity and traceability.

Next, based on the assessment of which challenges were most dominant for each adaptation measure, we identified the most relevant criteria from the full set of criteria in Table 2. For the sake of simplicity, we limited the relevant criteria to those related to challenges with a high score only. Flood-resilient building measures, for instance, are characterized by high spatial diversity. This means that two criteria are most important for the selection of instruments for this type of measure: "steers toward supplying sufficient levels of adaptation goods to hotspots most vulnerable to flooding" and "promotes diverse adaptation action that is tailored to a specific location to minimize costs". This way, we discerned a distinct set of relevant criteria for each adaptation measure (Table 5).

\section{Step 4: specific selection of instruments for an adaptation measure}

Based on the general assessment of policy instruments (Step 1; Table 3), we were able to identify policy instruments that scored high on the sets of relevant criteria for each adaptation measure (Step 3; Table 5). The results achieved by combining these steps are given in Table 6 . In the next sub-sections, we briefly discuss each adaptation measure in terms of appropriate instrument mixes.

\section{Green roofs}

This measure is characterized by relatively high levels of uncertainty and spatial diversity. We discerned the six criteria that are most relevant for the assessment of policy instruments for green roofs (Table 5) and then searched for policy instruments that received good scores for these six criteria based on the results in Table 3. The policy instrument that performs best, having medium to high scores on all six criteria, is the performance standard, implying a public governance arrangement with the local authority as the principal governor. The most important weakness of this instrument is that it scores low on input legitimacy, i.e., the criterion of serving all interests that are influenced by the policy, because it is a universal instrument that is not designed to cover all relevant interests (Table 6). However, no other instrument really scores well on that specific criterion. The most appropriate alternative to the performance standard would be the contractual agreement, which scores quite well on the six relevant criteria and also has a medium score for input legitimacy. One could combine these two instruments by introducing contractual agreements based on a performance standard. This would allow those public and private actors that enter into the contract to adjust the adaptation measure to their 
Table 4. Assessment of the four challenges for each of three adaptation measures.

\begin{tabular}{|c|c|c|c|}
\hline Adaptation measure & Challenge $\dagger$ & Score & Argumentation \\
\hline \multirow[t]{4}{*}{$\begin{array}{l}\text { Green roofs for rainfall } \\
\text { retention }\end{array}$} & Uncertainty & High & $\begin{array}{l}\text { There is considerable unpredictability in the frequency and intensity of rainfall events and } \\
\text { the timing and severity of impacts in different parts of the built environment; the } \\
\text { effectiveness of green roofs for rainfall retention in specific locations is highly uncertain, as } \\
\text { is their return on investment given their uncertain and often nonmonetizable benefits }\end{array}$ \\
\hline & $\begin{array}{l}\text { Spatial } \\
\text { diversity }\end{array}$ & High & $\begin{array}{l}\text { The amount of rainfall can vary spatially; more significantly, the extent of nuisance from } \\
\text { heavy rainfall and the effectiveness of green roofs heavily depends on the specific location, } \\
\text { amount of existing green space, type of building, slope of roof, etc. }\end{array}$ \\
\hline & Controversy & Low & $\begin{array}{l}\text { No-regret measure with many public and private benefits and no negative externalities for } \\
\text { others }\end{array}$ \\
\hline & $\begin{array}{l}\text { Social } \\
\text { complexity }\end{array}$ & Medium & $\begin{array}{l}\text { Number of actors involved is traceable and manageable; there is some complexity given the } \\
\text { split incentive issue between tenant interests and landlord/real estate investor interests }\end{array}$ \\
\hline \multirow[t]{4}{*}{$\begin{array}{l}\text { Flood-resilient building } \\
\text { measures }\end{array}$} & Uncertainty & Medium & $\begin{array}{l}\text { There is some knowledge/expectation about sea-level rise and increased river discharge, but } \\
\text { some degree of uncertainty remains; there is a medium level of knowledge regarding the } \\
\text { effectiveness of different adaptation measures }\end{array}$ \\
\hline & $\begin{array}{l}\text { Spatial } \\
\text { diversity }\end{array}$ & High & $\begin{array}{l}\text { The amounts of damage and risk differ considerably by location, house, type of measure } \\
\text { taken, etc. }\end{array}$ \\
\hline & Controversy & Low & $\begin{array}{l}\text { There is much agreement on the need for and specifications of building codes to make } \\
\text { buildings flood resilient, in particular, in case of new developments }\end{array}$ \\
\hline & $\begin{array}{l}\text { Social } \\
\text { complexity }\end{array}$ & Medium & $\begin{array}{l}\text { Number of actors involved is traceable and manageable; however, there could be diverging } \\
\text { views on acceptable risk and damage levels }\end{array}$ \\
\hline \multirow[t]{4}{*}{$\begin{array}{l}\text { Behavioral adaptation to } \\
\text { extreme heat }\end{array}$} & Uncertainty & Medium & $\begin{array}{l}\text { Hot days and heat waves can be predicted well in advance; the effectiveness of simple } \\
\text { behavioral measures to avoid or reduce heat stress is well known; such measures generally } \\
\text { involve low cost (little uncertainty regarding return on investment); however, one cannot be } \\
\text { certain of the extent of behavioral adaptation by vulnerable groups }\end{array}$ \\
\hline & $\begin{array}{l}\text { Spatial } \\
\text { diversity }\end{array}$ & High & $\begin{array}{l}\text { Build-up of heat indoors and outdoors depends very much on the location, amount of } \\
\text { green space, living environment, quality of housing, etc.; vulnerability to heat stress among } \\
\text { population groups is diverse }\end{array}$ \\
\hline & Controversy & Low & $\begin{array}{l}\text { No-regret measures; little effort is needed to adapt behavior; no negative externalities for } \\
\text { others }\end{array}$ \\
\hline & $\begin{array}{l}\text { Social } \\
\text { complexity }\end{array}$ & High & $\begin{array}{l}\text { The whole health and social network is/could be involved, in particular, in addressing the } \\
\text { problem of vulnerable people; some actors in the social network (family, neighbors) are } \\
\text { difficult to steer and to monitor }\end{array}$ \\
\hline
\end{tabular}

$\dagger$ Uncertainty about climate impacts on society and the effects, costs, and benefits of adaptation measures; Spatial diversity in terms of differential climate impacts on society; Controversy about adaptation goals and measures; Social complexity in terms of a multisector and multi-actor character of adaptation.

location-specific needs, suggesting an interactive governance arrangement. A potential weakness of the combination of these instruments is that they score relatively low on the indicator of "steers toward supplying sufficient levels of adaptation action" (Table 6). Finally, a sequential introduction can be designed by starting with the introduction of contractual agreements based on performance standards. As and when the green roof technology becomes well-known and accepted, and its costs drop (potentially due to economies of scale), a technical requirement for all new developments can be introduced, which scores well on the effectiveness criterion of sufficient levels of adaptation action. This would imply a shift from interactive to public governance over time.

\section{Flood-resilient building}

This type of measure is relatively less complex than green roofs or behavioral adaptation to extreme heat in the sense that it is primarily characterized by a high level of spatial diversity. Based on the two relevant criteria for dealing with spatial diversity, contractual agreements would seem to be most appropriate, so that areas specifically prone to flooding are addressed. Another appropriate instrument would be the use of smart subsidies directed toward these hotspots. Both instruments are in line with interactive governance. The downside of these instruments is that they do not guarantee a sufficient level of adaptation to flooding for everybody. This could leave some households less protected than others, which would perhaps be unfair, particularly if these households cannot afford the costs of adaptation measures. If experts and policy-makers find that safety for all is critical, the alternative would be to introduce a technical requirement for a specific set of flood-resilient measures through building codes in specific flood-prone areas. This would entail a public instead of an interactive arrangement.

\section{Behavioral adaptation to extreme heat}

In addition to high spatial diversity, which it has in common with the other two measures, this type of measure is characterized by a high level of social complexity. Hence, two additional criteria are of importance here: "serves all relevant interests that are influenced by the policy" and "supports the allocation and 
Table 5. Measure-specific relevant criteria for the selection of policy instruments.

\begin{tabular}{|c|c|c|c|c|}
\hline Adaptation measure & Challenge & $\begin{array}{l}\text { Extent to } \\
\text { which } \\
\text { challenge is } \\
\text { present }\end{array}$ & $\begin{array}{l}\text { Criteria at } \\
\text { risk }\end{array}$ & $\begin{array}{l}\text { Performance criteria for the selection of policy instruments } \\
\text { (see Table 2) }\end{array}$ \\
\hline \multirow{5}{*}{$\begin{array}{l}\text { Green roofs for rainfall } \\
\text { retention }\end{array}$} & Uncertainty & High & Effectiveness & Steers toward supplying sufficient levels of adaptation goods/services \\
\hline & & & Fairness & $\begin{array}{l}\text { Steers toward supplying sufficient levels of adaptation goods/services for } \\
\text { everyone now and in the future }\end{array}$ \\
\hline & & & $\begin{array}{l}\text { Legal } \\
\text { certainty }\end{array}$ & Offers legal certainty through understandable rules \\
\hline & & & Efficiency & Promotes flexible solutions that can be adjusted over time \\
\hline & $\begin{array}{c}\text { Spatial } \\
\text { diversity }\end{array}$ & High & Fairness & $\begin{array}{l}\text { Steers toward supplying sufficient levels of adaptation goods to } \\
\text { vulnerable hotspots }\end{array}$ \\
\hline $\begin{array}{l}\text { Flood-resilient building } \\
\text { measures }\end{array}$ & $\begin{array}{c}\text { Spatial } \\
\text { diversity }\end{array}$ & High & $\begin{array}{l}\text { Efficiency } \\
\text { Fairness }\end{array}$ & $\begin{array}{c}\text { Promotes diverse adaptation action tailored to a specific location } \\
\text { Steers toward supplying sufficient levels of adaptation goods to } \\
\text { vulnerable hotspots }\end{array}$ \\
\hline \multirow[t]{3}{*}{$\begin{array}{l}\text { Behavioral adaptation to } \\
\text { extreme heat }\end{array}$} & $\begin{array}{c}\text { Spatial } \\
\text { diversity }\end{array}$ & High & $\begin{array}{l}\text { Efficiency } \\
\text { Fairness }\end{array}$ & $\begin{array}{l}\text { Promotes diverse adaptation action tailored to a specific location } \\
\text { Steers toward supplying sufficient levels of adaptation goods to } \\
\text { vulnerable hotspots }\end{array}$ \\
\hline & $\begin{array}{l}\text { Social } \\
\text { complexity }\end{array}$ & High & $\begin{array}{l}\text { Efficiency } \\
\text { Input } \\
\text { legitimacy }\end{array}$ & $\begin{array}{l}\text { Promotes diverse adaptation action tailored to a specific location } \\
\text { Serves all relevant interests that are influenced by the policy without } \\
\text { excluding actors that have something at stake }\end{array}$ \\
\hline & & & Accountability & $\begin{array}{l}\text { Supports the allocation and transparency of responsibilities for } \\
\text { adaptation action for both the governors and the governed }\end{array}$ \\
\hline
\end{tabular}

transparency of responsibilities" (Table 5). No single instrument scores high on all four criteria (Table 3). Contractual agreements score best on all these criteria. An example of a contractual agreement is a covenant between local health authorities and civil society such as advocacy groups for the elderly and community workers, which stipulates responsibilities for active advice to elderly people. Contractual agreements, however, score medium on the criterion of serving all relevant interests. This would imply that several instruments are needed to cover the diversity of stakes involved in this socially complex issue. It is, for instance, obvious that population groups vulnerable to heat stress should be steered differently than the health practitioners who could keep an eye on them. Clearly, a requirement that forces a vulnerable individual to drink an extra glass of water is probably ineffective and would certainly not be considered legitimate. However, a requirement for health practitioners and social workers to track and monitor vulnerable individuals seems less inappropriate. In particular, for this adaptation measure, a mix of instruments is preferable. General heat health campaigns can be directed at the whole population and further targeted with specific information to vulnerable groups. Contractual agreements can be made between public health officials, health care institutions, and social/ community workers that make special arrangements for stimulating active engagement with particular vulnerable groups. The mix of instruments also implies a mix of governance arrangements.

Overall, the results indicate that contractual agreements are an appropriate policy instrument for the three adaptation measures in our study (Table 6). This is because the three measures score high on the governance challenge of spatial diversity. Contractual agreements permit governors to differentiate among vulnerable areas, regions, and population groups, and hence, to direct adaptation actions toward these hotspots. The varieties of appropriate instrument mixes among these three adaptation measures, therefore, stem from the differences in the extent of uncertainty and social complexity.

\section{CONCLUSION AND REFLECTION}

We presented a method for the selection of a mix of public and private policy instruments for promoting climate adaptation action. So far, the "how to adapt" question has tended to be dominated by debates on the adaptive capacities required (e.g., Eakin and Lemos 2006, Gupta et al. 2010, Juhola and Kruse 2014) and on overcoming the barriers that constrain action (e.g., Moser and Ekstrom 2010, Biesbroek 2014). We pose the employment of policy instruments as an alternative interface between adaptation planning and practice; the proposed method for their selection takes into account some of the key barriers and challenges as discussed in the literature.

Through the application of the method to three examples of climate adaptation measures, we arrive at the following four conclusions. First, the method fosters the assessment of various types of policy instruments with a comprehensive set of normative criteria commonly applied in policy practice. The bulk of the literature on the assessment of environmental policy instruments focuses on issues of effectiveness and efficiency only (e.g., Bemelmans-Videc et al. 1998, Bennear and Stavins 2007, Taylor et al. 2012) or deals with the assessment of one type of instrument only (e.g., Bennear and Stavins 2007). The few studies on the evaluation of policy instruments for climate adaptation tend to emphasize economic instruments and economic criteria (Hellegers and van Ierland 2003, Fankhauser et al. 2008, Filatova 2014). Furthermore, these normative criteria are specified for climate adaptation by taking into account four particular 
Table 6. Measure-specific assessment of policy instruments.

\begin{tabular}{|c|c|c|c|c|c|}
\hline $\begin{array}{l}\text { Adaptation } \\
\text { measure }\end{array}$ & $\begin{array}{l}\text { Dominant } \\
\text { challenge }\end{array}$ & $\begin{array}{l}\text { Relevant indicators to assess } \\
\text { policy instrument }\end{array}$ & $\begin{array}{l}\text { Policy instruments } \\
\text { that score high on } \\
\text { these relevant } \\
\text { criteria }\end{array}$ & $\begin{array}{l}\text { Policy instruments } \\
\text { that score high on } \\
\text { all relevant criteria }\end{array}$ & $\begin{array}{c}\text { Weaknesses of these } \\
\text { instruments: indicators for } \\
\text { which these instruments have } \\
\text { low scores }\end{array}$ \\
\hline \multirow[t]{4}{*}{$\begin{array}{l}\text { Green roofs for } \\
\text { rainfall retention }\end{array}$} & Uncertainty & $\begin{array}{c}\text { Steers toward supplying sufficient } \\
\text { levels of adaptation goods/ } \\
\text { services }\end{array}$ & $\begin{array}{l}\text { Technical } \\
\text { requirements \& } \\
\text { Performance } \\
\text { standards }\end{array}$ & $\begin{array}{l}\text { Performance } \\
\text { standards }\end{array}$ & $\begin{array}{l}\text { Risk of not serving all relevant } \\
\text { interests that are influenced by } \\
\text { the policy without excluding } \\
\text { actors or groups that have } \\
\text { something at stake }\end{array}$ \\
\hline & & $\begin{array}{l}\text { Steers toward supplying sufficient } \\
\text { levels of adaptation goods/ } \\
\text { services for everyone now and in } \\
\text { the future } \\
\text { Offers legal certainty through } \\
\text { understandable rules } \\
\text { Promotes flexible solutions that } \\
\text { can be adjusted over time }\end{array}$ & & & \\
\hline & $\begin{array}{l}\text { Spatial } \\
\text { diversity }\end{array}$ & $\begin{array}{l}\text { Steers toward supplying sufficient } \\
\text { levels of adaptation goods to } \\
\text { vulnerable hotspots }\end{array}$ & $\begin{array}{c}\text { Contractual } \\
\text { agreements \& } \\
\text { Smart subsidies }\end{array}$ & & $\begin{array}{l}\text { Risk of not steering toward } \\
\text { supplying sufficient levels of } \\
\text { adaptation goods (for everyone } \\
\text { now and in the future) }\end{array}$ \\
\hline & & $\begin{array}{c}\text { Promotes diverse adaptation } \\
\text { action tailored to a specific } \\
\text { location }\end{array}$ & & & \\
\hline \multirow[t]{2}{*}{$\begin{array}{l}\text { Flood-resilient } \\
\text { building measures }\end{array}$} & $\begin{array}{l}\text { Spatial } \\
\text { diversity }\end{array}$ & $\begin{array}{l}\text { Steers toward supplying sufficient } \\
\text { levels of adaptation goods to } \\
\text { vulnerable hotspots }\end{array}$ & $\begin{array}{c}\text { Contractual } \\
\text { agreements \& } \\
\text { Smart subsidies }\end{array}$ & $\begin{array}{l}\text { Contractual } \\
\text { agreements \& } \\
\text { Smart subsidies }\end{array}$ & $\begin{array}{l}\text { Risk of not steering toward } \\
\text { supplying sufficient levels of } \\
\text { adaptation goods (for everyone } \\
\text { now and in the future) }\end{array}$ \\
\hline & & $\begin{array}{l}\text { Promotes diverse adaptation } \\
\text { action tailored to a specific } \\
\text { location }\end{array}$ & & & \\
\hline \multirow[t]{3}{*}{$\begin{array}{l}\text { Behavioral } \\
\text { adaptation to } \\
\text { extreme heat }\end{array}$} & $\begin{array}{l}\text { Spatial } \\
\text { diversity }\end{array}$ & $\begin{array}{l}\text { Steers toward supplying sufficient } \\
\text { levels of adaptation goods to } \\
\text { vulnerable hotspots }\end{array}$ & $\begin{array}{l}\text { Contractual } \\
\text { agreements \& } \\
\text { Smart subsidies }\end{array}$ & $\begin{array}{l}\text { Contractual } \\
\text { agreements }\end{array}$ & $\begin{array}{l}\text { Risk of not steering toward } \\
\text { supplying sufficient levels of } \\
\text { adaptation goods (for everyone } \\
\text { now and in the future) }\end{array}$ \\
\hline & & $\begin{array}{l}\text { Promotes diverse adaptation } \\
\text { action tailored to a specific } \\
\text { location }\end{array}$ & & & \\
\hline & $\begin{array}{l}\text { Social } \\
\text { complexity }\end{array}$ & $\begin{array}{l}\text { Serves all relevant interests that } \\
\text { are influenced by the policy } \\
\text { without excluding actors that } \\
\text { have something at stake } \\
\text { Supports the allocation and } \\
\text { transparency of responsibilities } \\
\text { for adaptation action for both the } \\
\text { governors and the governed }\end{array}$ & $\begin{array}{l}\text { Contractual } \\
\text { agreements }\end{array}$ & & \\
\hline
\end{tabular}

challenges to the governance of adaptation, namely uncertainty, spatial diversity, controversy, and social complexity. This adaptation-specific set of criteria allows for a deliberate rather than a routine or intuitive choice of instruments for climate adaptation.

Second, the step-wise approach of the method enables a structured and interactive process that fosters dialog and consensus building among experts, resulting in a deliberative choice of policy instruments. This resonates with adaptation scholars, who agree that deliberation and dialog between policymakers, scientists, and stakeholders is needed to deal with the inherent uncertainty and social complexity of climate adaptation (e.g., Paavola 2008, Adger et al. 2009, Juhola and Westerhoff 2011).

Third, there is no question of a one-size-fits-all policy instrument mix for climate adaptation. The examples of adaptation measures we used show variety in the extent to which the four governance challenges manifest themselves, resulting in different levels of appropriateness for different policy instrument mixes. Again, this seems to fit with the bulk of adaptive capacity/governance literature, which stresses the need for variety, flexibility, and tailormade solutions (e.g., Adger et al. 2009, Saavedra and Budd 2009, Gupta et al. 2010). 
Finally, the examples of adaptation measures also show that the method opens up avenues for launching new policy instrument mixes. This, in turn, has implications for the division of responsibilities between public and private actors. A shift in policy instruments may therefore trigger a shift in governance arrangements for a certain adaptation issue or measure.

We end by reflecting on some limitations to our study and, based on those, suggesting some ideas for future work. The process for the selection of policy instruments was completed by a group of six experts representing three scientific disciplines of relevance to the broad field of policy studies. Repeating our study with more or other experts, including experts in policy-making and policy practice, would eliminate potential biases we are unaware of and increase the robustness of our judgments. Policy-makers may place different weight on certain performance criteria, in resonance with the political or social culture to which they are bound. Instrument choices can also be influenced by considerations and constraints in the political and societal context (Hood 1983) or by the attributes of the policy network (Bressers and O'Toole 1998), phenomena which we did not consider. Another limitation is the choice of adaptation examples, which focused on urban adaptation measures. This could bias the set of criteria employed. Future work could evaluate the comprehensiveness of the set of criteria by testing it with other adaptation measures, which might also entail additional policy instruments. Finally, based on our experience with presenting the method to a group of policy-makers involved in adaptation planning for fresh water supply in the Netherlands, we found that the method was perceived to be quite challenging but also complex. Therefore, we argue that scientific experts may be needed to facilitate the process and give structure to the debates. These experts should have knowledge of the adaptation theme at hand and should be able to promote the understanding of the performance criteria and to foster exchange of argumentation among policy-makers. Ultimately, they can check the validity of these argumentations to avoid negotiated nonsense (van de Riet 2003).

Responses to this article can be read online at: http://www.ecologyandsociety.org/issues/responses. php/6639

\section{Acknowledgments:}

This research was funded by the Dutch Knowledge for Climate Research Programme http://knowledgeforclimate.climateresearchnetherlands. $n l l$.

\section{LITERATURE CITED}

Aaheim, A., T. Dokken, S. Hochrainer, A. Hof, E. Jochem, R. Mechler, and D. van Vuuren. 2010. National responsibilities for adaptation strategies: lessons from four modelling frameworks. Pages 87-112 in M. Hulme and H. Neufeldt, editors. Making climate change work for us: European perspectives on adaptation and mitigation strategies. Cambridge University Press, Cambridge, UK.
Adger, W. N., K. Brown, J. Fairbrass, A. Jordan, J. Paavola, S. Rosendo, and G. Seyfang. 2003. Governance for sustainability: towards a 'thick' analysis of environmental decisionmaking. Environment and Planning A 35(6):1095-1110. http://dx.doi. org/10.1068/a35289

Adger, W. N., S. Dessai, M. Goulden, M. Hulme, I. Lorenzoni, D. R. Nelson, L. O. Naess, J. Wolf, and A. Wreford. 2009. Are there social limits to adaptation to climate change? Climatic Change 93(3-4):335-354. http://dx.doi.org/10.1007/s10584-008-9520$\underline{z}$

Aerts, J. C. J. H., and W. J. W. Botzen. 2011. Flood-resilient waterfront development in New York City: bridging flood insurance, building codes, and flood zoning. Annals of the New York Academy of Sciences 1227:1-82. http://dx.doi.org/10.1111/ j.1749-6632.2011.06074.X

Archie, K. M., L. Dilling, J. B. Milford, and F. C. Pampel. 2012. Climate change and western public lands: a survey of U.S. federal land managers on the status of adaptation efforts. Ecology and Society 17(4): 20. http://dx.doi.org/10.5751/ES-05187-170420

Atkinson, G., F. Machado, and S. Mourato. 2000. Balancing competing principles of environmental equity. Environment and Planning A 32(10):1791-1806. http://dx.doi.org/10.1068/a32106

Bekkers, V., and A. Edwards. 2007. Legitimacy and democracy: a conceptual framework for assessing governance practices. Pages 35-60 in V. Bekkers, G. Dijkstra, A. Edwards, and M. Fenger, editors. Governance and the democratic deficit: assessing the democratic legitimacy of governance practices. Ashgate, Hampshire, UK.

Bemelmans-Videc, M.-L., R. C. Rist, and E. Vedung. 1998. Carrots, sticks and sermons: policy instruments and their evaluation. Transaction Publishers, New Brunswick, New Jersey, USA.

Bennear, L. S., and R. N. Stavins. 2007. Second-best theory and the use of multiple policy instruments. Environmental and Resource Economics 37(1):111-129. http://dx.doi.org/10.1007/ s10640-007-9110-y

Berkhout, F. 2005. Rationales for adaptation in EU climate change policies. Climate Policy 5(3):377-391. http://dx.doi. org/10.3763/cpol.2005.0521

Berkhout, F. 2012. Adaptation to climate change by organizations. Wiley Interdisciplinary Reviews: Climate Change 3 (1):91-106. http://dx.doi.org/10.1002/wcc.154

Berkhout, F., J. Hertin, and D. M. Gann. 2006. Learning to adapt: organisational adaptation to climate change impacts. Climatic Change 78(1):135-156. http://dx.doi.org/10.1007/s10584-006-9089-3

Bernstein, S. 2005. Legitimacy in global environmental governance. Journal of International Law and International Relations 1(1-2):139-166. [online] URL: http://www.jilir.org/docs/ vol1no1-2/JILIR $\% 201 \% 281-2 \% 29 \% 20$ Bernstein-Legitimacy $\% 20 \mathrm{in} \%$ 20Global $\% 20$ Environmental $\% 20$ Governance.pdf.

Berrang-Ford, L., J. D. Ford, and J. Paterson. 2011. Are we adapting to climate change? Global Environmental Change 21 (1):25-33. http://dx.doi.org/10.1016/j.gloenvcha.2010.09.012 
Biermann, F., and A. Gupta. 2011. Accountability and legitimacy in earth system governance: a research framework. Ecological Economics 70(11):1856-1864. http://dx.doi.org/10.1016/j. ecolecon.2011.04.008

Bierbaum, R., J. B. Smith, A. Lee, M. Blair, L. Carter, F. S. Chapin III, P. Fleming, S. Ruffo, M. Stults, S. McNeeley, E. Wasley, and L. Verduzco. 2013. A comprehensive review of climate adaptation in the United States: more than before, but less than needed. Mitigation and Adaptation Strategies for Global Change 18 (3):361-406. http://dx.doi.org/10.1007/s11027-012-9423-1

Biesbroek, R. 2014. Challenging barriers in the governance of climate change adaptation. Dissertation. Wageningen University, Wageningen, The Netherlands.

Biesbroek, G. R., R. J. Swart, T. R. Carter, C. Cowan, T. Henrichs, H. Mela, M. D. Morecroft, and D. Rey. 2010. Europe adapts to climate change: comparing national adaptation strategies, Global Environmental Change 20(3):440-450. http://dx.doi.org/10.1016/ j.gloenvcha.2010.03.005

Botchway, F. N. 2001. Good governance: the old, the new, the principle, and the elements. Florida Journal of International Law 13(2):159-210.

Bressers, H. T. A., and L. J. O’Toole, Jr. 1998. The selection of policy instruments: a network-based perspective. Journal of Public Policy 18(3):213-239. http://dx.doi.org/10.1017/

$\underline{\mathrm{S} 0143814 X 98000117}$

Brukas, V., and O. Sallnäs. 2012. Forest management plan as a policy instrument: carrot, stick or sermon? Land Use Policy 29 (3):605-613. http://dx.doi.org/10.1016/j.landusepol.2011.10.003

Carter, T., and L. Fowler. 2008. Establishing green roof infrastructure through environmental policy instruments. Environmental Management 42(1):151-164. http://dx.doi.org/10.1007/ $\underline{\mathrm{s} 00267-008-9095-5}$

Crabbé, A., and P. Leroy. 2008. The handbook of environmental policy evaluation. Earthscan, London, UK.

De Bruin, K., R. B. Dellink, A. Ruijs, L. Bolwidt, A. van Buuren, J. Graveland, R. S. de Groot, P. J. Kuikman, S. Reinhard, R. P. Roetter, V. C. Tassone, A. Verhagen, and E. C. van Ierland. 2009. Adapting to climate change in The Netherlands: an inventory of climate adaptation options and ranking of alternatives. Climatic Change 95(1-2):23-45. http://dx.doi.org/10.1007/s10584-009-9576-4

Dingwerth, K. 2007. The new transnationalism: transnational governance and democratic legitimacy. Palgrave Macmillan, Basingstoke, UK.

Dovers, S. R., and A. A. Hezri. 2010. Institutions and policy processes: the means to the ends of adaptation. Wiley Interdisciplinary Reviews: Climate Change 1(2):212-231. http://dx. doi.org/10.1002/wcc. 29

Driessen, P. P. J., C. Dieperink, F. van Laerhoven, H. A. C. Runhaar, and W. J. V. Vermeulen. 2012. Towards a conceptual framework for the study of shifts in modes of environmental governance - experiences from the Netherlands. Environmental Policy and Governance 22(3):143-160. http://dx.doi.org/10.1002/ eet. 1580
Driessen, P. P. J., and H. F. M. W. van Rijswick. 2011. Normative aspects of climate adaptation policy. Climate Law 2(4):559-581. http://dx.doi.org/10.3233/CL-2011-051

Eakin, H., and M. C. Lemos. 2006. Adaptation and the state: Latin America and the challenge of capacity-building under globalization. Global Environmental Change 16(1):7-18. http://dx. doi.org/10.1016/j.gloenvcha.2005.10.004

Fankhauser, S., S. Agrawala, D. Hanrahan, G. Pope, J. Skees, C. Stephens, and S. Yasmine. 2008. Economic and policy instruments to promote adaptation. Pages 85-133 in S. Agrawala and S. Fankhauser, editors. Economic aspects of adaptation to climate change: costs, benefits and policy instruments. OECD, Paris, France.

Fankhauser, S., J. B. Smith, and R. S. J. Tol. 1999. Weathering climate change: some simple rules to guide adaptation decisions. Ecological Economics 30(1):67-78. http://dx.doi.org/10.1016/ $\underline{\text { S0921-8009(98)00117-7 }}$

Ferraro, P. J. 2008. Asymmetric information and contract design for payments for environmental services. Ecological Economics 65 (4):810-821. http://dx.doi.org/10.1016/j.ecolecon.2007.07.029

Few, R., K. Brown, and E. L. Tompkins. 2007. Public participation and climate change adaptation: avoiding the illusion of inclusion. Climate Policy 7(1):46-59. http://dx.doi.org/10.3763/ cpol.2007.0704

Filatova, T. 2014. Market-based instruments for flood risk management: a review of theory, practice and perspectives for climate adaptation policy. Environmental Science and Policy 37:227-242. http://dx.doi.org/10.1016/j.envsci.2013.09.005

Fuller, L. L. 1969. The morality of law. Revised edition. Yale University Press, New Haven, Connecticut, USA.

Füssel, H.-M. 2007. Adaptation planning for climate change: concepts, assessment approaches, and key lessons. Sustainability Science 2(2):265-275. http://dx.doi.org/10.1007/s11625-007-0032y

Gifford, R. 2011. The dragons of inaction: psychological barriers that limit climate change mitigation and adaptation. American Psychologist 66(4):290-302. http://dx.doi.org/10.1037/a0023566

Glasbergen, P. 1992. Seven steps towards an instrumentation theory for environmental policy. Policy and Politics 20(3):191-200. http://dx.doi.org/10.1332/030557392782718698

Grasso, M. 2007. A normative ethical framework in climate change. Climatic Change 81(3-4):223-246. http://dx.doi. org/10.1007/s10584-006-9158-7

Gunningham, N., and P. Grabosky. 1998. Smart regulation: designing environmental policy. Clarendon Press, Oxford, UK.

Gunningham, N., and D. Sinclair. 2002. Leaders and laggards: next-generation environmental regulation. Greenleaf, Sheffield, $\mathrm{UK}$.

Gupta, A. 2010. Transparency in global environmental governance: a coming of age? Global Environmental Politics 10 (3):1-9. http://dx.doi.org/10.1162/GLEP_e_00011 
Gupta, J., C. Termeer, J. Klostermann, S. Meijerink, M. van den Brink, P. Jong, S. Nooteboom, and E. Bergsma. 2010. The adaptive capacity wheel: a method to assess the inherent characteristics of institutions to enable the adaptive capacity of society. Environmental Science and Policy 13(6):459-471. http:// dx.doi.org/10.1016/j.envsci.2010.05.006

Hellegers, P., and E. van Ierland. 2003. Policy instruments for groundwater management in the Netherlands. Environmental and Resource Economics 26(1):163-172. http://dx.doi.org/10.1023/ A:1025685621417

Hinkel, J., S. Bisaro, T. E. Downing, M. E. Hofmann, K. Lonsdale, D. McEvoy, and J. D. Tabara. 2010. Learning to adapt: re-framing climate change adaptation. Pages 113-134 in M. Hulme and $\mathrm{H}$. Neufeldt, editors. Making climate change work for us: European perspectives on adaptation and mitigation strategies. Cambridge University Press, Cambridge, UK.

Hood, C. 1983. The tools of government. Macmillan, London, UK.

Hood, C. 2007. Intellectual obsolescence and intellectual makeovers: reflections on the tools of government after two decades. Governance: An International Journal of Policy, Administration, and Institutions 20(1):127-144. http://dx.doi. org/10.1111/j.1468-0491.2007.00347.x

Howlett, M. 1991. Policy instruments, policy styles, and policy implementation: national approaches to theories of instrument choice. Policy Studies Journal 19(2):1-21. http://dx.doi. org/10.1111/j.1541-0072.1991.tb01878.X

Huitema, D., E. Mostert, W. Egas, S. Moellenkamp, C. PahlWostl, and R. Yalcin. 2009. Adaptive water governance: assessing the institutional prescriptions of adaptive (co-)management from a governance perspective and defining a research agenda. Ecology and Society 14(1): 26. [online] URL: http://www.ecologyandsociety. org/vol14/iss1/art26/.

Jagers, S. C., and G. Duus-Otterström. 2008. Dual climate change responsibility: on moral divergences between mitigation and adaptation. Environmental Politics 17(4):576-591. http://dx.doi. org/10.1080/09644010802193443

Johnson, C. L., and S. J. Priest. 2008. Flood risk management in England: a changing landscape of risk responsibility? International Journal of Water Resources Development 24 (4):513-525. http://dx.doi.org/10.1080/07900620801923146

Juhola, S., and S. Kruse. 2014. A framework for analysing regional adaptive capacity assessments: challenges for methodology and policy making. Mitigation and Adaptation Strategies for Global Change, in press. http://dx.doi.org/10.1007/s11027-013-9481-z

Juhola, S., and L. Westerhoff. 2011. Challenges of adaptation to climate change across multiple scales: a case study of network governance in two European countries. Environmental Science and Policy 14(3):239-247. http://dx.doi.org/10.1016/j.envsci.2010.12.006

Keessen, A. M., and H. F. M. W. van Rijswick. 2012. Adaptation to climate change in European water law and policy. Utrecht Law Review 8(3):38-50. [online] URL: http://www.utrechtlawreview. org/index.php/ulr/article/view/URN $\% 3$ ANBN $\% 3$ ANL $\% 3 A U I \%$ $\underline{\text { 3A10-1-112907. }}$.
Kjær, A. M. 2004. Governance. Polity Press, Malden, Massachusetts, USA.

Kleindorfer, P. R., and H. Kunreuther. 1999. The complementary roles of mitigation and insurance in managing catastrophic risks. Risk Analysis 19(4):727-738. http://dx.doi.org/10.1111/j.1539-6924.1999. $\underline{\mathrm{tb} 00442 . \mathrm{x}}$

Kunreuther, H., and M. Pauly. 2006. Rules rather than discretion: lessons from Hurricane Katrina. Journal of Risk and Uncertainty 33(1-2):101-116. http://dx.doi.org/10.1007/s11166-006-0173-x

Lindley, S. J., J. F. Handley, D. McEvoy, E. Peet, and N. Theuray. 2007. The role of spatial risk assessment in the context of planning for adaptation in UK urban areas. Built Environment 33(1):46-69. http://dx.doi.org/10.2148/benv.33.1.46

Lockie, S. 2013. Market instruments, ecosystem services, and property rights: assumptions and conditions for sustained social and ecological benefits. Land Use Policy 31:90-98. http://dx.doi. org/10.1016/j.landusepol.2011.08.010

Lowe, D., K. L. Ebi, and B. Forsberg. 2011. Heatwave early warning systems and adaptation advice to reduce human health consequences of heatwaves. International Journal of Environmental Resources and Public Health 8(12):4623-4648. http://dx.doi. org/10.3390/ijerph8124623

Mees, H. L. P., and P. P. J. Driessen. 2011. Adaptation to climate change in urban areas: climate-greening London, Rotterdam, and Toronto. Climate Law 2(2):251-280. http://dx.doi.org/10.3233/ $\underline{\text { CL-2011-036 }}$

Mees, H. L. P., P. P. J. Driessen, and H. A. C. Runhaar. 2012. Exploring the scope of public and private responsibilities for climate adaptation. Journal of Environmental Policy and Planning 14(3):305-330. http://dx.doi.org/10.1080/1523908X.2012.707407

Mees, H. L. P., P. P. J. Driessen, and H. A. C. Runhaar. 2014. Legitimate adaptive flood risk governance beyond the dikes: the cases of Hamburg, Helsinki and Rotterdam. Regional Environmental Change 14(2):671-682. http://dx.doi.org/10.1007/ s10113-013-0527-2

Mees, H. L. P., P. P. J. Driessen, H. A. C. Runhaar, and J. Stamatelos. 2013. Who governs climate adaptation? Getting green roofs for stormwater retention off the ground. Journal of Environmental Planning and Management 56(6):802-825. http:// dx.doi.org/10.1080/09640568.2012.706600

Moser, S. C., and J. A. Ekstrom. 2010. A framework to diagnose barriers to climate change adaptation. Proceedings of the National Academy of Sciences 107(51):22026-22031. http://dx.doi. org/10.1073/pnas.1007887107

Nelissen, N. 2002. The administrative capacity of new types of governance. Public Organization Review 2(1):5-22. http://dx.doi. org/10.1023/A:1016019302732

Oikonomou, V., and C. J. Jepma. 2008. A framework on interactions of climate and energy policy instruments. Mitigation and Adaptation Strategies for Global Change 13(2):131-156. http:// dx.doi.org/10.1007/s11027-007-9082-9

Paavola, J. 2008. Science and social justice in the governance of adaptation to climate change. Environmental Politics 17 (4):644-659. http://dx.doi.org/10.1080/09644010802193609 
Paavola, J., and W. N. Adger. 2006. Fair adaptation to climate change. Ecological Economics 56(4):594-609. http://dx.doi. org/10.1016/j.ecolecon.2005.03.015

Popelier, P. 2000. Legal certainty and principles of proper law making. European Journal of Law Reform 3:321-342.

Preston, B. L., R. M. Westaway, and E. J. Yuen. 2011. Climate adaptation planning in practice: an evaluation of adaptation plans from three developed nations. Mitigation and Adaptation Strategies for Global Change 16(4):407-438. http://dx.doi. org/10.1007/s11027-010-9270-X

Radbruch, G. 1970. Rechtsphilosophie. C. F. Müller Verlag, Heidelberg, Germany.

Runhaar, H., H. Mees, A. Wardekker, J. van der Sluijs, and P. P. J. Driessen. 2012. Adaptation to climate change-related risks in Dutch urban areas: stimuli and barriers. Regional Environmental Change 12(4):777-790. http://dx.doi.org/10.1007/s10113-012-0292-7

Saavedra, C., and W. W. Budd. 2009. Climate change and environmental planning: working to build community resilience and adaptive capacity in Washington State, USA. Habitat International 33(3):246-252. http://dx.doi.org/10.1016/j. habitatint.2008.10.004

Schär, C., and G. Jendritzky. 2004. Hot news from summer 2003. Nature 432:559-560. http://dx.doi.org/10.1038/432559a

Taylor, C., S. Pollard, S. Rocks, and A. Angus. 2012. Selecting policy instruments for better environmental regulation: a critique and future research agenda. Environmental Policy and Governance 22(4):268-292. http://dx.doi.org/10.1002/eet.1584

Tennekes, J., P. P. J. Driessen, H. F. M. W. van Rijswick, and L. van Bree. 2014. Out of the comfort zone: institutional context and the scope for legitimate climate adaptation policy. Journal of Environmental Policy and Planning, in press. http://dx.doi. org/10.1080/1523908X.2013.836961

Termeer, C., A. Dewulf, H. van Rijswick, A. van Buuren, D. Huitema, S. Meijerink, T. Rayner, and M. Wiering. 2011. The regional governance of climate adaptation: a framework for developing legitimate, effective, and resilient governance arrangements. Climate Law 2(2):159-179. http://dx.doi. org/10.3233/CL-2011-032

Thompson, G., J. Frances, R. Levacic, and J. Mitchell. 1991. Markets, hierarchies and networks: the coordination of social life. Sage, London, UK.

Tompkins, E. L., and H. Eakin. 2012. Managing private and public adaptation to climate change. Global Environmental Change 22(1):3-11. http://dx.doi.org/10.1016/j.gloenvcha.2011.09.010

Urwin, K., and A. Jordan. 2008. Does public policy support or undermine climate change adaptation? Exploring policy interplay across different scales of governance. Global Environmental Change 18(1):180-191. http://dx.doi.org/10.1016/j.gloenvcha.2007.08.002

Vabo, S. I., and A. Røiseland. 2012. Conceptualizing the tools of government in urban network governance. International Journal of Public Administration 35(14):934-946. http://dx.doi. org/10.1080/01900692.2012.691243
Van Buuren, A., P. P. J. Driessen, G. Teisman, and M. van Rijswick. 2014. Toward legitimate governance strategies for climate adaptation in the Netherlands: combining insights from a legal, planning, and network perspective. Regional Environmental Change 14(3)1021-1033. http://dx.doi.org/10.1007/ s10113-013-0448-0

Van de Riet, O. 2003. Policy analysis in multi-actor policy settings: navigating between negotiated nonsense and superfluous knowledge. Dissertation. Eburon, Delft, The Netherlands.

Van Vuuren, D. P., M. Isaac, Z. W. Kundzewicz, N. Arnell, T. Barker, P. Criqui, F. Berkhout, H. Hilderink, J. Hinkel, A. Hof, A. Kitous, T. Kram, R. Mechler, and S. Scrieciu. 2011. The use of scenarios as the basis for combined assessment of climate change mitigation and adaptation. Global Environmental Change 21(2):575-591. http://dx.doi.org/10.1016/j.gloenvcha.2010.11.003

Vedung, E. 1998. Policy instruments: typologies and theories. Pages 1-58 in M. L. Bemelmans-Videc, R. C. Rist, and E. Vedung, editors. Carrots, sticks and sermons: policy instruments and their evaluation. Transaction Publishers, New Brunswick, New Jersey, USA.

Wamsler, C., and E. Brink. 2014. Interfacing citizens' and institutions' practice and responsibilities for climate change adaptation. Urban Climate 7:64-91. http://dx.doi.org/10.1016/j. uclim.2013.10.009

Weber, M., P. P. J. Driessen, and H. A. C. Runhaar. 2014. Evaluating environmental policy instruments mixes; a methodology illustrated by noise policy in the Netherlands. Journal of Environmental Planning and Management, in press. http://dx.doi.org/10.1080/09640568.2013.808609

Wilby, R. L., and K. Vaughan. 2011. Hallmarks of organisations that are adapting to climate change. Water and Environment Journal 25(2):271-281. http://dx.doi.org/10.1111/j.1747-6593.2010.00220. $\underline{\mathrm{X}}$

World Health Organization. 2007. Improving public health responses to extreme weather events. IV: preventing heat-related health effects. The prevention framework. World Health Organization, Geneva, Switzerland.

Wurzel, R. K. W., A. Jordan, A. R. Zito, and L. Brückner. 2003. From high regulatory state to social and ecological market economy? New environmental policy instruments in Germany. Environmental Politics 12(1):115-136. http://dx.doi. org/10.1080/09644010412331308214 
Appendix 1. generic assessment of a technical requirement

Please click here to download file 'appendix1.xlsx'. 